medRxiv preprint doi: https://doi.org/10.1101/2021.06.21.21259227; this version posted June 25, 2021. The copyright holder for this preprint (which was not certified by peer review) is the author/funder, who has granted medRxiv a license to display the preprint in perpetuity.

It is made available under a CC-BY 4.0 International license .

\title{
Meta-Analytic Evidence of Depression and Anxiety in Eastern Europe during the COVID-19 Pandemic
}

Stephen X. Zhang ${ }^{1}$ Saylor O. Miller ${ }^{2}, \mathrm{Wen} \mathrm{Xu}^{3}$, Allen Yin ${ }^{4}$, Bryan Z. Chen ${ }^{5}$, Andrew Delios ${ }^{6}$, Rebecca Kechen Dong ${ }^{7}$, Richard Z. Chen ${ }^{8}$, Roger S. McIntyre ${ }^{9}$, Xue Wan ${ }^{10}$, Senhu Wang ${ }^{11}$, Jiyao Chen $^{12 *}$

\section{Author Affiliations}

1. Faculty of Professions, University of Adelaide, Adelaide SA 5005, Australia, stephen.x.zhang@gmail.com

2. College of Business, Oregon State University, 416 Austin Hall Corvallis OR, USA, millesay@oregonstate.edu

3. Business School China, University of Nottingham Ningbo China, Ningbo 315100 , China, wen.xu@nottingham.edu.cn

4. School of Humanities, Southeast University, Nanjing, China, allen-yin@hotmail.com

5. Crescent Valley High School, Corvallis, OR 97330, USA, chenzbryan@gmail.com

6. College of Business, University of Adelaide, SA 5001, Australia, delios9580@gmail.com

7. Business School, University of South Australia, Adelaide SA 5001,

Australia, Rebecca.dong@unisa.edu.au

8. Crescent Valley High School, Corvallis, OR 97330, USA, richardziychen@gmail.com

9. Department of Psychiatry and Pharmacology, University of Toronto, Canada,

Roger.McIntyre@uhn.ca

10. School of Economics and Management, Tongji University, Shanghai, China, wanxue@,tongji.edu.cn

11 Department of Sociology, National University of Singapore, UK. socsw@,nus.edu.sg

12. College of Business, Oregon State University, 416 Austin Hall Corvallis OR, USA, Jiyao.chen@oregonstate.edu

*Corresponding author: 416 Austin Hall Corvallis OR, USA, Jiyao.chen@,oregonstate.edu 
medRxiv preprint doi: https://doi.org/10.1101/2021.06.21.21259227; this version posted June 25, 2021. The copyright holder for this preprint (which was not certified by peer review) is the author/funder, who has granted medRxiv a license to display the preprint in perpetuity.

It is made available under a CC-BY 4.0 International license.

\title{
Meta-Analytic Evidence of Depression and Anxiety Mental Health in Eastern Europe during the COVID-19 Pandemic
}

\begin{abstract}
Objective: To perform a systematic and meta-analysis on the prevalence rates of mental health symptoms including anxiety and depression during the COVID-19 pandemic in the general population in Eastern Europe, as well as three select sub-populations: students, general healthcare workers, and frontline healthcare workers.
\end{abstract}

Data sources: Studies in PubMed, Embase, Web of Science, Psycinfo, and medRxiv up to February 6, 2021.

Eligibility criteria and data analysis: Prevalence rates of mental health symptoms in the general population and key sub-populations during the COVID-19 pandemic in Eastern Europe. Data were pooled using a random-effects meta-analysis to estimate the prevalence rates of anxiety and depression.

Results: The meta-analysis identifies and includes 21 studies and 26 independent samples in Eastern Europe. Poland $(n=4)$, Serbia $(n=4)$, Russia $(n=3)$, and Croatia $(n=3)$ had the greatest number of studies. To our knowledge, no studies have been conducted in eleven Eastern European countries including Hungary, Slovakia, and Slovenia. The pooled prevalence of anxiety in 18 studies with 22 samples was 30\% (95\% CI: $24 \%-37 \%)$ and pooled prevalence of depression in 18 studies with 23 samples was 27\% (95\% CI: $21 \%-34 \%)$.

Implications: The cumulative evidence from the meta-analysis reveals high prevalence rates of clinically significant symptoms during the COVID-19 pandemic in Eastern Europe. The findings suggest evidence of a potential mental health crisis in Eastern Europe during the ongoing COVID-19 pandemic. Our synthesis also reveals a relative lack of studies in certain Eastern 
medRxiv preprint doi: https://doi.org/10.1101/2021.06.21.21259227; this version posted June 25, 2021. The copyright holder for this preprint (which was not certified by peer review) is the author/funder, who has granted medRxiv a license to display the preprint in perpetuity.

It is made available under a CC-BY 4.0 International license .

European countries as well as high heterogeneities among the existing studies, calling for more effort to achieve evidence-based mental healthcare in Eastern Europe.

Keywords: COVID-19; Epidemic; General Population; Healthcare Workers; Frontline

Healthcare Workers; Psychiatry

Highlights:

- The pooled prevalence of anxiety and depression were $30 \%$ and $27 \%$ in Eastern Europe, respectively.

Trial registration: CRD42020224458 
medRxiv preprint doi: https://doi.org/10.1101/2021.06.21.21259227; this version posted June 25, 2021. The copyright holder for this preprint (which was not certified by peer review) is the author/funder, who has granted medRxiv a license to display the preprint in perpetuity.

It is made available under a CC-BY 4.0 International license.

\section{INTRODUCTION}

The COVID-19 pandemic (1), with more than 170 million confirmed cases and 3.5 million deaths by May 2021 (2), has taken a toll on mental health, due to fear of illness and hospitalization, the effects of social isolation, and economic downturn $(2,3)$. To assess mental health during the COVID-19 pandemic, several meta-analyses have polled the prevalence of mental health symptoms in several countries or regions, such as China (4), Southeast Asia (5), and South Asia (6). These meta-analytical studies have provided crucial evidence on mental health in specific regions and uncovered important heterogeneity to enable evidence-based healthcare in those regions. However, the literature still lacks meta-analytical evidence on the prevalence of mental health symptoms in Eastern Europe - a vast region that has been affected by the COVID-19 pandemic in the past year. Eastern Europe has struggled to manage the pandemic, and has suffered from high mortality and morbidity rates. Mental health research has historically overlooked Eastern Europe (7), where mental health epidemiology is still regarded with intense stigma and direct evidence on the topic remains scarce (8). Even prior to the pandemic, Eastern Europe has been relatively weak in identifying people with mental health symptoms (7). Furthermore, recent changes in healthcare systems and lack of per capita funding for community mental health resources presents some unique issues in mental health practice at the system level in Eastern Europe (7). Such issues have resulted in a lack of evidence-based mental health practices (8).

This study aims to address this knowledge gap by presenting the first meta-analysis to quantify the prevalence of anxiety and depression during the COVID-19 pandemic in Eastern Europe. We performed a systematic review of the prevalence of anxiety and depression of the general population as well as healthcare workers (HCW) during the COVID-19 pandemic in 
medRxiv preprint doi: https://doi.org/10.1101/2021.06.21.21259227; this version posted June 25, 2021. The copyright holder for this preprint (which was not certified by peer review) is the author/funder, who has granted medRxiv a license to display the preprint in perpetuity.

It is made available under a CC-BY 4.0 International license .

Eastern European countries. Such meta-analytical pooled prevalence of mental health symptoms provides crucial evidence to enable evidence-based healthcare policies and resource deployment and also creates opportunities for decision-making on prevention.

\section{METHODOLOGY}

This systematic review and meta-analysis follows the Preferred Reporting Items for Systematic Reviews and Meta-Analyses (PRISMA) statement 2019 and is registered in the International Prospective Register of Systematic Reviews (PROSPERO: CRD42020224458) (9).

\subsection{Data sources and database search strategy}

A comprehensive literature search was performed in the following databases: Web of Science, PUBMED, EMBASE, and medRxiv based on keywords shown in Appendix 1 with Boolean operators.

\subsection{Selection criteria}

The articles were selected based on the following criteria:

1. Design: Cohort or cross-sectional

2. Context: COVID-19 pandemic

3. Population: Including adult populations from the general population, general students, medical students, frontline HCWs, or general HCWs

4. Outcome: Anxiety, depression, or insomnia

5. Instrument: Validated measurement tools or scales of anxiety, depression, and insomnia including cut-off scores.

6. Language: English

7. Region: This meta-analysis includes the following Eastern European countries based on the EuroVoc definition of Eastern Europe: Albania, Armenia, Azerbaijan, Belarus, 
medRxiv preprint doi: https://doi.org/10.1101/2021.06.21.21259227; this version posted June 25, 2021. The copyright holder for this preprint (which was not certified by peer review) is the author/funder, who has granted medRxiv a license to display the preprint in perpetuity.

It is made available under a CC-BY 4.0 International license.

Bosnia and Herzegovina, Bulgaria, Croatia, Czech Republic, Georgia, Hungary, Kosovo, Moldova, Montenegro, North Macedonia, Poland, Romania, Russia, Serbia, Slovakia, Slovenia, Turkey and Ukraine.

8. Time: between February 1, 2020 and February 2021

We excluded articles with the following criteria:

1. Measurements: Non-validated mental health instruments or non-validated cut-off scores.

2. Population: Specific adult populations such as COVID-19 patients, inpatients, or adults under quarantine, children, or adolescents.

3. Methodological approaches: Non-primary studies including reviews, meta-analyses, qualitative studies, case studies, interventional studies, interviews, or news reports.

\subsection{Empirical study selection}

Two coders (BZC \& AD) independently reviewed titles and abstracts of empirical studies retrieved through initial screening criteria. Conflicts of eligibility were referred to a third coder (RKD). The articles included after the title and abstract screening underwent a full-text evaluation.

\subsection{Data extraction}

A comprehensive screening protocol was developed. The following variables were collected from each study: author, title, country, starting and ending dates of data collection, study design, population, sample size, respondent rate, female proportion rate, age range and mean, outcome, outcome level, instruments, cut-off scores, and prevalence. If possible, we coded the prevalence at the severity of mild above, moderate above, and severe. For those studies that reported the mild, moderate, and severe prevalence, we converted them into mild above, 
medRxiv preprint doi: https://doi.org/10.1101/2021.06.21.21259227; this version posted June 25, 2021. The copyright holder for this preprint (which was not certified by peer review) is the author/funder, who has granted medRxiv a license to display the preprint in perpetuity.

It is made available under a CC-BY 4.0 International license.

moderate above, and severe prevalence. For these studies that only reported the overall prevalence, we specified their severity if their cut-off points were reported.

The protocol was followed by two independent coders in pairs (WX \& AY, BZC \& AD, RZC \& SM). The corresponding authors of empirical studies without prevalence data or missing essential data were contacted by a designated researcher (WX). The reason(s) for emailing authors and excluding studies were recorded. After both coders in each pair had independently coded their studies, they then cross-checked their information and discussed possible differences. If disagreements remained, a third coder (SM) settled disagreements after independently coding the study.

\subsection{Bias risk}

Risk of bias was assessed at the empirical article collection and meta-analysis level. Throughout the data collection process, two coders used the Mixed Methods Appraisal Tool (MMAT) to independently determine the appropriateness of measurement tools, the risk of nonresponse bias, and the sample representativeness of each empirical study (10). A quality score ranging from 0 to 7 was assigned to each empirical study. A MMAT quality score higher than 6 indicated low bias risk, a score between 5 and 6 indicated medium risk, and a score below 5 indicated high bias risk (10). The MMAT scores were compared using a standardized crosscheck protocol. A final check of inter-coder consistency was performed by a third independent coder (RKD). A sensitivity analysis was conducted to assess the risk of bias of the study.

\subsection{Methods of analysis}

Stata 16.1 was used to pool rates of anxiety and depression, using metaprop (11). The random-effects model was used to calculate pooled estimates of outcome prevalence between populations. The $\mathrm{I}^{2}$ statistic was used to calculate variance difference from effect sizes in order to 
medRxiv preprint doi: https://doi.org/10.1101/2021.06.21.21259227; this version posted June 25, 2021. The copyright holder for this preprint (which was not certified by peer review) is the author/funder, who has granted medRxiv a license to display the preprint in perpetuity.

It is made available under a CC-BY 4.0 International license.

quantify heterogeneity rather than sampling error (12). Subgroup analyses were performed on population groups (i.e., general population, students, general HCWs, and frontline HCWs), mental health disorder (i.e., anxiety, depression, and insomnia), outcome severity (i.e., mild above, moderate above, severe). We also performed subgroup analysis on EU (European Union) membership, i.e. EU countries vs. Non-EU countries. Lastly, we did subgroup analysis by regions, i.e., the greater Balkan region known more formally as Southeastern Europe and the rest. The greater Balkan region of southeastern Europe includes Albania, Bosnia and Herzegovina, Bulgaria, Croatia, Kosovo, Montenegro, North Macedonia, Romania, Serbia, Slovenia, and Turkey. The remaining Eastern European countries, including Czech Republic, Poland, Russia, and Ukraine, were categorized as Non-Southeastern Europe.

\section{RESULTS}

\subsection{Screening results}

A PRISMA flowchart (Figure 1) illustrates the systematic review process, which is part of a large research effort to examine the prevalence of mental health symptoms across regions and countries during the COVID-19 pandemic. A total of 6949 studies were identified in the search. Of these studies, 3603 were duplicates and were excluded. The initial screening of 3346 studies produced 684 studies eligible for further full-text evaluation. Through detailed full-text evaluation, 524 studies were excluded. Two rounds of emails were sent to the authors of studies with missing data for the meta-analyses. Prevalence data from the email responses was added to 8 of the 29 empirical studies, bringing the total number of empirical studies for the meta-analyses to 168 . Of the 168 studies, 23 empirical studies covered Eastern Europe (13-35). As there were only two studies that examined the prevalence of insomnia $(19,22)$, insomnia was excluded from further analysis. The meta-analysis included the remaining 21 studies with 26 unique samples 
medRxiv preprint doi: https://doi.org/10.1101/2021.06.21.21259227; this version posted June 25, 2021. The copyright holder for this preprint (which was not certified by peer review) is the author/funder, who has granted medRxiv a license to display the preprint in perpetuity.

It is made available under a CC-BY 4.0 International license.

that reported 87 prevalence rates. Some empirical studies include multiple independent samples.

For example, Stojanov et al. surveyed frontline HCWs and general HCWs (17).

\subsection{Characteristics of included studies}

Table 1 shows the characteristics of the 21 studies. The countries that had the most studies are Poland and Serbia (19.1\%, n=4), followed by Croatia and Russia $(14.39 \%, n=3)$, Albania (9.5\%, $\mathrm{n}=2)$, and one study each from Bosnia and Herzegovina, Bulgaria, Czech Republic, Kosovo, and Ukraine. Samples were distributed between populations as follows: general population $(42.3 \%, n=11)$, general HCWs $(26.9 \%, n=7)$, general (i.e. non-medical) students $(15.4 \%, n=4)$, and frontline HCWs $(15.4 \%, n=4)$. The prevalence of mental health symptoms was found for the following categories: mild above $(34.5 \%, n=30)$, moderate above $(37.9 \%, n=33)$, severe above $(19.6 \%, n=17)$, and overall $(8.1 \%, n=7)$. Most of the studies $(95.7 \%, n=20)$ used cross-sectional designs. The median percentage of female respondents was $68.8 \%$ with a range of $0 \%$ to $100 \%$. The response rates ranged from $0.7 \%$ to $98.5 \%$ with a median of $56.7 \%$. The sample size ranged from 83 to 3306 with a median of 843 respondents.

\subsection{Mental health outcome prevalence}

A random-effects meta-analysis model showed the pooled prevalence of depression of 18 empirical studies $(13,15-22,24-35)$ (including 23 samples and 43 prevalence rates) was $27 \%$ (95\% CI: 21\% - 34\%, I²: 99.6\%) (Table 2). This pooled prevalence represents a total of 22,195 respondents. Several depression instruments were used: most frequently the Depression, Anxiety, and Stress Scale (DASS-21) (52.2\%), followed by Patient Health Questionnaire (PHQ)-

9 (30.4\%), Beck Depression Inventory (BDI) (4.4\%), Hospital Anxiety and Depression Scale (HADS) (4.4\%), and Brief Symptom Inventory (BSI) (4.4\%). 
medRxiv preprint doi: https://doi.org/10.1101/2021.06.21.21259227; this version posted June 25, 2021. The copyright holder for this preprint (which was not certified by peer review) is the author/funder, who has granted medRxiv a license to display the preprint in perpetuity.

It is made available under a CC-BY 4.0 International license .

The pooled prevalence of anxiety was 30\% (95\% CI: 24\% - 37\%, I²: 99.6\%) (Table 2). Data from 18 studies (13-15, 17-26, 28-35), including 22 samples and 44 prevalence rates), reported anxiety prevalence out of a total of 21,120 participants. The DASS-21 was used most frequently (56.5\%), followed by Generalized Anxiety Symptoms 7-items scale (GAD-7) (30.4\%), HADS (4.4\%), and BSI (4.4\%).

The aggregated prevalence of either anxiety or depression in frontline HCWs was $41 \%$ (95\% CI: $\left.23-60 \%, \mathrm{I}^{2}: 99.4 \%\right)$ and 33\% in general HCWs (95\% CI: $\left.22-45 \%, \mathrm{I}^{2}: 99.4 \%\right)$ (Table 2). The overall prevalence of mental health symptoms in Southeastern Europe countries was lower $\left(27 \%, 95 \%\right.$ CI: $\left.22 \%-32 \%, \mathrm{I}^{2}: 99.4 \%\right)$ than in non-Southeastern Europe countries $(32 \%$, 95\% CI: 24\% - 40\%, I $\left.\mathrm{I}^{2}: 99.7 \%\right)$ (Table 2).

Subgroup analysis revealed that while depression prevalence was $34 \%$ for both general HCWs (95\% CI: 18\% - 51\%, I $\left.\mathrm{I}^{2}: 99.5 \%\right)$ and frontline HCWs (95\% CI: $\left.2 \%-79 \%, \mathrm{I}^{2}: 99.5 \%\right)$, anxiety prevalence was significantly higher among frontline HCWs (46\%; 95\% CI: 25\% - 67\%, I²: 99.4\%) than among general HCWs (33\%; 95\% CI: 16\% - 51\%, $\left.\mathrm{I}^{2}: 99.5 \%\right)$ (Table 3). The prevalence of anxiety and depression in student populations was $31 \%$ and $32 \%$, respectively. In the general population, prevalence of depression and anxiety was $20 \%$ and $22 \%$, respectively (Table 3 ). European Union (EU) countries in Eastern Europe had a prevalence of 34\% (95\% CI: 27\% - 42\%, $\mathrm{I}^{2}: 99.7 \%$ ), which is a bit higher than that Eastern European countries without EU memberships $\mathrm{S}$ (28\%; 95\% CI: 22\% - 35\%, I $\left.\mathrm{I}^{2}: 99.8 \%\right)$. Southeastern Europe countries (the greater Balkan region) had pooled anxiety and depression prevalence rates of 31\% (95\% CI: $\left.23 \%-40 \%, \mathrm{I}^{2}: 99.5 \%\right)$ and 35\% (95\% CI: 21\% - 51\%, I 2 : 99.4\%), respectively (Table 3). In non-Southeastern Europe countries, prevalence of anxiety and depression was 29\% (95\% CI: $\left.20 \%-40 \%, \mathrm{I}^{2}: 99.6 \%\right)$ and 55\% (95\% CI: 46\% - 65\%, I²: 99.8\%) (Table 3). 
medRxiv preprint doi: https://doi.org/10.1101/2021.06.21.21259227; this version posted June 25, 2021. The copyright holder for this preprint (which was not certified by peer review) is the author/funder, who has granted medRxiv a license to display the preprint in perpetuity.

It is made available under a CC-BY 4.0 International license.

\subsection{Article quality}

Study quality was analyzed using the Mixed Methods Appraisal Tool (MMAT). Of the 21 studies, 3 studies (14.29\%) were categorized as high quality and 18 studies $(85.71 \%)$ categorized as medium quality (Table 1). The subgroup analysis suggests the studies with high quality reported lower prevalence of clinically significant symptoms of mental health symptoms in Eastern Europe (Table 2).

\subsection{Sensitivity analysis}

A sensitivity analysis was conducted using a DOI plot and Luis Furuya-Kanamori (LFK) index to detect any publication bias in the meta-analysis. Conventional funnel plots have been previously determined to be inaccurate for meta-analyses of pooled proportion studies (34). Additionally, DOI plots in combination with LFK indices use higher power and sensitivity for bias detection than both funnel plots and Egger's regression (36). A DOI plot, in addition to a LFK index, can better graphically represent publication bias. An asymmetrical triangle indicates potential publication bias whereas a symmetrical triangle suggests no publication bias (36). A LFK index score within \pm 1 indicates 'no asymmetry'. When the LFK index score exceeds \pm 1 but is within \pm 2 it indicates 'minor asymmetry' and when the score exceeds \pm 2 'major asymmetry' is indicated. The studies on Eastern Europe, as shown in Figure 3, have 'minor asymmetry' based on an index score of 1.50 and therefore minor publication bias is likely. The impact of publication status and sample size was tested and no significant influence was found.

\section{DISCUSSION}

This meta-analysis on 21 empirical studies of 25,246 adults provides the first evidence on the pooled prevalence rates of mental health symptoms in Eastern Europe during the COVID-19 pandemic. The pooled prevalence rates of anxiety and depression in Eastern Europe were 30\% 
medRxiv preprint doi: https://doi.org/10.1101/2021.06.21.21259227; this version posted June 25, 2021. The copyright holder for this preprint (which was not certified by peer review) is the author/funder, who has granted medRxiv a license to display the preprint in perpetuity.

It is made available under a CC-BY 4.0 International license .

and 27\% (Table 2). Subgroup analyses revealed several key findings: frontline HCWs indicated higher rates of mental disorder symptoms, especially anxiety (46\%, 95\% CI: 25\% - 67\%, $\mathrm{I}^{2}$ : $99.4 \%$, a high percentage of adults suffered from mild or greater severity of anxiety $(56 \%, 95 \%$ CI: $44 \%-67 \%, I^{2}: 99.4 \%$ ), a higher rate of depression was found in non-Southeastern Europe $\left(55 \%, 95 \%\right.$ CI: $\left.46 \%-65 \%, I^{2}: 99.8 \%\right)$, and the choice of instruments represents a significant source of heterogeneity on the pooled prevalence of anxiety and depression symptoms.

\subsection{Comparing with prior meta-analyses}

First, we discuss the pooled prevalence rates of this meta-analysis by comparing them with prior meta-analytical findings during the COVID-19 pandemic in other regions as benchmarks. Our pooled prevalence of depression of 27\% in Eastern Europe was within the range of similar meta-analyses results in China. Prior meta-analyses of depression in China indicated heterogeneous pooled prevalence ranging from $24 \%$ to $32 \%$ in adult populations (4, 37-39). Our pooled prevalence of depression in Eastern Europe was significantly lower than prevalence in Southeast Asia (34\%, p<0.001) (5), Spain $(35 \%, \mathrm{p}<0.001)(40)$ and Africa (45\%, p $<0.001$ ) (41) and prevalence rates in a cross-continent meta-analysis including empirical studies from China, India, Iran, Iraq, Italy, Japan, Nepal, Nigeria, Spain, and the UK $(34 \%, p<0.001)$ (42).

The pooled prevalence of anxiety of $30 \%$ in this Eastern Europe meta-analysis was significantly higher than the pooled rates reported in Spain $(20 \%, \mathrm{p}<0.001)(40)$ and was similar to those among the general population in China $(30 \%, \mathrm{p}=0.653)(37)$. However, prevalence of anxiety symptoms was significantly lower in Eastern Europe compared to prevalence in Africa $(37 \%, \mathrm{p}<0.001)(40)(41)$ and Southeast Asia $(41 \%, \mathrm{p}<0.001)(5)$, and to prevalence in a cross- 
medRxiv preprint doi: https://doi.org/10.1101/2021.06.21.21259227; this version posted June 25, 2021. The copyright holder for this preprint (which was not certified by peer review) is the author/funder, who has granted medRxiv a license to display the preprint in perpetuity.

It is made available under a CC-BY 4.0 International license.

continent meta-analysis (i.e., China, India, Iran, Iraq, Italy, Japan, Nepal, Nigeria, Spain and the UK) $(32 \%, \mathrm{p}<0.001)(42)$.

\subsection{Subgroup analyses}

Our results show that frontline HCWs suffered from anxiety symptoms at a significantly higher rate compared to other populations in Eastern Europe. Overall, frontline HCWs had the highest prevalence of mental health symptoms including anxiety (46\%) and depression (34\%), followed by general HCWs (anxiety: 33\%, depression: 34\%) and subsequently students (anxiety: $31 \%$, depression: $32 \%$ ) and the general population (anxiety: $22 \%$, depression: $20 \%$ ). This finding indicates heterogeneity of mental health symptoms among distinct populations in Eastern Europe. Comparatively, a meta-analysis in China also found a lower pooled prevalence of anxiety (27\%) and depression (20\%) among general HCWs compared to prevalence of anxiety (40\%) and depression (24\%) in frontline HCWs (43). Notwithstanding this finding, it needs to be emphasized that there are heterogeneous results on the prevalence of psychopathology reported in HCWs in China (44).

The prevalence of mental health symptoms during the COVID-19 pandemic is not homogeneous across regions. European Union (EU) countries in Eastern Europe had a prevalence of $34 \%$, which a bit higher than that Eastern European countries without EU memberships at 28\%. The greater Balkan region of Southeastern Europe and non-Southeastern Europe exhibited a similar rate of anxiety (31\% vs. 29\%) but a very different rate of depression symptoms (35\% vs. 55\%). Such mental health symptom differences provide important evidence for future research directions to offer insight into these significant differences. It is possible that the economic, cultural, social, and political factors of individual countries and broader regions as well as heterogeneous COVID-19 policies, such as the length and stringency of shutdowns, 
medRxiv preprint doi: https://doi.org/10.1101/2021.06.21.21259227; this version posted June 25, 2021. The copyright holder for this preprint (which was not certified by peer review) is the author/funder, who has granted medRxiv a license to display the preprint in perpetuity.

It is made available under a CC-BY 4.0 International license.

lockdowns, and quarantine, may influence mental health symptoms such as anxiety and depression differentially (45). We also note that the pooled prevalence rates of anxiety and depression are significantly influenced by the choice of the instruments in the primary studies. For example, anxiety prevalence measured by DASS-21 was $25 \%$ (95\% CI: $16 \%-34 \%, \mathrm{I}^{2}$ : 99.1\%) and 43\% using HADS (CI: 17\% - 71\%, $\mathrm{I}^{2}: 99.1 \%$ ), suggesting future research should pay attention to the choice of the instruments.

\subsection{Implications}

The systematic review reveals that eleven Eastern European countries had not been subject to a single study on the topic. Future studies should focus on countries without empirical data including Armenia, Azerbaijan, Belarus, Georgia, Hungary, Moldova, Montenegro, North Macedonia, Romania, Slovakia, and Slovenia. For practical purposes, healthcare organizations in locations without country-level evidence on mental health may use our evidence at the regional level as approximate evidence. These findings also emphasize the importance of further empirical research and subsequent meta-analyses on Eastern Europe countries in order to better prioritize resource allocation.

The understanding of mental disorder prevalence within specific regions can help to create targeted healthcare policy by healthcare organizations such as WHO. The responses to the COVID-19 pandemic have been remarkably homogeneous across governments (45). Available WHO guidance has focused on preventing local progression of infectious diseases rather than achieving regional herd behavior (45). Eastern European mental healthcare is dependent on large psychiatric institutions with an emphasis on in-patient psychiatry (7), which may not be effectively addressing widespread anxiety and depression symptoms. Mental health research has historically been overlooked in Eastern Europe (7), where mental health epidemiology is still 
medRxiv preprint doi: https://doi.org/10.1101/2021.06.21.21259227; this version posted June 25, 2021. The copyright holder for this preprint (which was not certified by peer review) is the author/funder, who has granted medRxiv a license to display the preprint in perpetuity.

It is made available under a CC-BY 4.0 International license.

regarded with intense stigma and direct evidence on the topic remains scarce (8). Existing stigma, along with a lack of evidence-based community-wide mental health services, may be contributing to high prevalence of mental health disorders. Furthermore, recent changes in healthcare systems and lack of per capita funding for community mental health resources may contribute to the unique situation in Eastern Europe mental health, which still lacks evidencebased mental health practices (7). With this backdrop, the meta-analysis provides quantitative evidence revealing a high prevalence of mental health symptoms in Eastern Europe serve as the basis for inform more targeted healthcare practices, such as evidence-based occupational guidelines which identify and focus on vulnerable populations during acute crises (2).

\subsection{Study limitations}

First, as we only included studies in English, there is an expected language bias. Second, our meta-analysis is limited by the limitations of the empirical studies. Due to the nature of lockdowns and social isolation during the pandemic, many of the studies used convenience samples, reducing the accurate representation of respective populations. Varying tools of data collection used different cut-off scores. In future research, mental health evaluation of a random sample would yield representative data. Additionally, the meta-analysis is limited by the populations and mental health symptoms represented in the available empirical studies. Only two studies covered insomnia, and therefore insomnia was not represented in the meta-analysis. Further studies focused on insomnia prevalence would contribute to a pooled prevalence of insomnia and improve supporting data for evidence-based medical interventions.

\subsection{Conclusion}

Understanding the prevalence of mental health symptoms during the COVID-19 pandemic represents the first step to enable evidence-based medical practices by assessing the 
medRxiv preprint doi: https://doi.org/10.1101/2021.06.21.21259227; this version posted June 25, 2021. The copyright holder for this preprint (which was not certified by peer review) is the author/funder, who has granted medRxiv a license to display the preprint in perpetuity.

It is made available under a CC-BY 4.0 International license .

mental health situation during the COVID-19 pandemic. We hope the meta-analysis in Eastern

Europe can inform mental health practices as well as encourage future research on mental health during the ongoing COVID-19 pandemic.

\section{References}

[1] Pappa S, Ntella V, Giannakas T, Giannakoulis VG, Papoutsi E, Katsaounou P. Prevalence of depression, anxiety, and insomnia among healthcare workers during the COVID-19 pandemic: A systematic review and meta-analysis. Brain, Behavior, and Immunity. 2020;88:901-7. doi:

10.1016/j.bbi.2020.05.026.

[2] Holmes EA, O'Connor RC, Perry VH, Tracey I, Wessely S, Arseneault L, et al. Multidisciplinary research priorities for the COVID-19 pandemic: a call for action for mental health science. The Lancet Psychiatry. 2020;7(6):547-60. doi: 10.1016/S2215-0366(20)30168-1. [3] Xiong J, Lipsitz O, Nasri F, Lui LMW, Gill H, Phan L, et al. Impact of COVID-19 pandemic on mental health in the general population: A systematic review. Journal of Affective Disorders. 2020;277:55-64. doi: 10.1016/j.jad.2020.08.001.

[4] Chen X, Chen J, Zhang M, Chen RZ, Dong RK, Dong Z, et al. One Year of Evidence on Mental Health in China in the COVID-19 Crisis - A Systematic Review and Meta-Analysis. Medrxiv. 2021. doi: 10.1101/2021.02.01.21250929.

[5] Pappa S, Chen J, Barnet J, Zhang A, Dong RK, Xu W, et al. A Systematic Review and MetaAnalysis of the Mental Health Impact of the Covid-19 Pandemic in Southeast Asia. 2021. doi: 10.1101/2021.06.03.21258001.

[6] Hossain MM, Rahman M, Trisha NF, Tasnim S, Nuzhath T, Hasan NT, et al. Prevalence of anxiety and depression in South Asia during COVID-19: A systematic review and meta-analysis. Heliyon. 2021;7(4):e06677. doi: 10.1016/j.heliyon.2021.e06677.

[7] Krupchanka D, Winkler P. State of mental healthcare systems in Eastern Europe: do we really understand what is going on? BJPsych international. 2016;13(4):96-9. doi:

$10.1192 / \mathrm{s} 2056474000001446$.

[8] Franic T, Dodig-Curkovic K. Covid-19, child and adolescent mental health - Croatian

(in)experience. Irish Journal of Psychological Medicine. 2020;37(3):214-7. doi:

10.1017/ipm.2020.55.

[9] Moher D, Shamseer L, Clarke M, Ghersi D, Liberati A, Petticrew M, et al. Preferred reporting items for systematic review and meta-analysis protocols (PRISMA-P) 2015 statement. Systematic Reviews. 2015;4(1):1. doi: 10.1186/2046-4053-4-1.

[10] Hong QN, Pluye P, Fàbregues S, Bartlett G, Boardman F, Cargo M, et al. The Mixed Methods Appraisal Tool (MMAT) version 2018 for information professionals and researchers. Education for Information. 2018;34(4):285-91. doi: 10.3233/EFI-180221.

[11] Nyaga VN, Arbyn M, Aerts M. Metaprop: a Stata command to perform meta-analysis of binomial data. Archives of Public Health. 2014;72(1):39. doi: 10.1186/2049-3258-72-39.

[12] Higgins JP, et al. Cochrane handbook for systematic reviews of interventions. John Wiley \& Sons. 2019. 
medRxiv preprint doi: https://doi.org/10.1101/2021.06.21.21259227; this version posted June 25, 2021. The copyright holder for this preprint (which was not certified by peer review) is the author/funder, who has granted medRxiv a license to display the preprint in perpetuity. It is made available under a CC-BY 4.0 International license .

[13] Salopek-Ziha D, Hlavati M, Gvozdanovic Z, Gasic M, Placento H, General County Hospital Našice N, Croatia, et al. Differences in distress and coping with the Covid-19 stressor in nurses and physicians. Psychiatria Danubina. 2020;32(2):287-93. doi: 10.24869/psyd.2020.287. [14] Rogowska AM, Kuśnierz C, Bokszczanin A. Examining Anxiety, Life Satisfaction, General Health, Stress and Coping Styles During COVID-19 Pandemic in Polish Sample of University Students. Psychology Research and Behavior Management. 2020;Volume 13:797-811. doi: 10.2147/PRBM.S266511.

[15] Nekliudov NA, Blyuss O, Cheung KY, Petrou L, Genuneit J, Sushentsev N, et al. Excessive Media Consumption About COVID-19 is Associated With Increased State Anxiety: Outcomes of a Large Online Survey in Russia. Journal of Medical Internet Research. 2020;22(9):e20955. doi: $10.2196 / 20955$.

[16] Sljivo A, Kacamakovic M, Quraishi I, Dzubur Kulenovic A. Fear and depression among residents of Bosnia and Herzegovina during COVID-19 outbreak - internet survey. Psychiatria Danubina. 2020;32(2):266-72. doi: 10.24869/psyd.2020.266.

[17] Stojanov J, Malobabic M, Stanojevic G, Stevic M, Milosevic V, Stojanov A. Quality of sleep and health-related quality of life among health care professionals treating patients with coronavirus disease-19. International Journal of Social Psychiatry. 2020:002076402094280. doi: 10.1177/0020764020942800.

[18] Winkler P, Formanek T, Mlada K, Kagstrom A, Mohrova Z, Mohr P, et al. Increase in prevalence of current mental disorders in the context of COVID-19: analysis of repeated nationwide cross-sectional surveys. Epidemiology and Psychiatric Sciences. 2020;29:e173. doi: $10.1017 /$ S2045796020000888.

[19] Secosan I, Virga D, Crainiceanu ZP, Bratu T. The Mediating Role of Insomnia and Exhaustion in the Relationship between Secondary Traumatic Stress and Mental Health Complaints among Frontline Medical Staff during the COVID-19 Pandemic. Behavioral Sciences. 2020;10(11):164. doi: 10.3390/bs10110164.

[20] Kowalski J, Marchlewska M, Molenda Z, Górska P, Gawęda Ł. Adherence to safety and self-isolation guidelines, conspiracy and paranoia-like beliefs during COVID-19 pandemic in Poland - associations and moderators. Psychiatry Research. 2020;294:113540. doi: 10.1016/j.psychres.2020.113540.

[21] Gallopeni F, Bajraktari I, Selmani E, Tahirbegolli IA, Sahiti G, Muastafa A, et al. Anxiety and depressive symptoms among healthcare professionals during the Covid-19 pandemic in Kosovo: A cross sectional study. Journal of Psychosomatic Research. 2020;137:110212. doi: 10.1016/j.jpsychores.2020.110212.

[22] Wańkowicz P, Szylińska A, Rotter I. Assessment of Mental Health Factors among Health Professionals Depending on Their Contact with COVID-19 Patients. International Journal of Environmental Research and Public Health. 2020;17(16):5849. doi: 10.3390/ijerph17165849. [23] Cypryańska M, Nezlek JB. Anxiety as a mediator of relationships between perceptions of the threat of COVID-19 and coping behaviors during the onset of the pandemic in Poland. PLOS ONE. 2020;15(10):e0241464. doi: 10.1371/journal.pone.0241464.

[24] Dzhambov AM, Lercher P, Browning MHEM, Stoyanov D, Petrova N, Novakov S, et al. Does greenery experienced indoors and outdoors provide an escape and support mental health during the COVID-19 quarantine? Environmental Research. 2020:110420. doi:

10.1016/j.envres.2020.110420. 
medRxiv preprint doi: https://doi.org/10.1101/2021.06.21.21259227; this version posted June 25, 2021. The copyright holder for this preprint (which was not certified by peer review) is the author/funder, who has granted medRxiv a license to display the preprint in perpetuity. It is made available under a CC-BY 4.0 International license.

[25] Galić M, Mustapić L, Šimunić A, Sić L, Cipolletta S. COVID-19 Related Knowledge and Mental Health: Case of Croatia. Frontiers in Psychology. 2020;11:567368. doi:

10.3389/fpsyg.2020.567368.

[26] Rogowska AM, Pavlova I, Kuśnierz C, Ochnik D, Bodnar I, Petrytsa P. Does Physical Activity Matter for the Mental Health of University Students during the COVID-19 Pandemic? Journal of Clinical Medicine. 2020;9(11). doi: 10.3390/jcm9113494.

[27] Mechili EA, Saliaj A, Kamberi F, Girvalaki C, Peto E, Patelarou AE, et al. Is the mental health of young students and their family members affected during the quarantine period? Evidence from the COVID-19 pandemic in Albania. Journal of Psychiatric and Mental Health Nursing. 2020. doi: 10.1111/jpm.12672.

[28] Margetić B, Peraica T, Stojanović K, Ivanec D. Predictors of emotional distress during the COVID-19 pandemic; a Croatian study. Personality and Individual Differences.

2021;175:110691. doi: 10.1016/j.paid.2021.110691.

[29] Markovic I, Nikolovski S, Milojevic S, Zivkovic D, Knezevic S, Mitrovic A, et al. Public trust and media influence on anxiety and depression levels among skilled workers during the COVID-19 outbreak in Serbia. Vojnosanitetski pregled. 2020;77(11):1201-9. doi:

10.2298/VSP200713108M.

[30] Mosolova E, Chung S, Sosin D, Mosolov S. Stress and Anxiety among Healthcare Workers Associated with COVID-19 Pandemic in Russia. Psychiatria Danubina. 2020;32(3-4):549-56. doi: $10.24869 /$ psyd.2020.549.

[31] Karpenko OA, Syunyakov TS, Kulygina MA, Pavlichenko AV, Chetkina AS, Andrushchenko AV. Impact of COVID-19 pandemic on anxiety, depression and distress - online survey results amid the pandemic in Russia. Consortium Psychiatricum. 2020;1(1):8-20. doi: 10.17650/2712-7672-2020-1-1-8-20.

[32] Bachilo EV, Barylnik JB, Shuldyakov AA, Efremov AA, Novikov DE. Mental Health of Medical Workers During the COVID-19 Pandemic in Russia: Results of a Cross-Sectional Study. preprint. Psychiatry and Clinical Psychology, 2020 2020-07-29. Report No.

[33] Antonijevic J, Binic I, Zikic O, Manojlovic S, Tosic - Golubovic S, Popovic N. Mental health of medical personnel during the COVID - 19 pandemic. Brain and Behavior. 2020;10(12). doi: $10.1002 /$ brb3.1881.

[34] Vujčić I, Safiye T, Milikić B, Popović E, Dubljanin D, Dubljanin E, et al. Coronavirus Disease 2019 (COVID-19) Epidemic and Mental Health Status in the General Adult Population of Serbia: A Cross-Sectional Study. International Journal of Environmental Research and Public Health. 2021;18(4):1957. doi: 10.3390/ijerph18041957.

[35] Sigorski D, Sobczuk P, Osmola M, Kuć K, Walerzak A, Wilk M, et al. Impact of COVID19 on anxiety levels among patients with cancer actively treated with systemic therapy. ESMO Open. 2020;5(5):e000970. doi: 10.1136/esmoopen-2020-000970.

[36] Furuya-Kanamori L, Barendregt JJ, Doi S. A new improved graphical and quantitative method for detecting bias in meta-analysis. International Journal of Evidence-Based Healthcare. 2018;16(4):195-203. doi: 10.1097/XEB.0000000000000141.

[37] Wu T, Jia X, Shi H, Niu J, Yin X, Xie J, et al. Prevalence of mental health problems during the COVID-19 pandemic: A systematic review and meta-analysis. Journal of Affective Disorders. 2021;281:91-8. doi: 10.1016/j.jad.2020.11.117.

[38] Luo M, Guo L, Yu M, Jiang W, Wang H. The psychological and mental impact of coronavirus disease 2019 (COVID19) on medical staff and general public - A systematic review 
medRxiv preprint doi: https://doi.org/10.1101/2021.06.21.21259227; this version posted June 25, 2021. The copyright holder for this preprint (which was not certified by peer review) is the author/funder, who has granted medRxiv a license to display the preprint in perpetuity. It is made available under a CC-BY 4.0 International license .

and meta-analysis. Psychiatry Research. 2020;291(113190). doi:

10.1016/j.psychres.2020.113190.

[39] Ren X, Huang W, Pan H, Huang T, Wang X, Ma Y. Mental Health During the Covid-19 Outbreak in China: a Meta-Analysis. The Psychiatric Quarterly. 2020;91(4):1033-45. doi: 10.1007/s11126-020-09796-5.

[40] Chen RZ, Zhang SX, Xu W, Yin A, Dong RK, Chen BZ, et al. A Systematic Review and Meta-Analysis on Mental Illness Symptoms in Spain in the COVID-19 Crisis. Medrxiv. 2021. doi: 10.1101/2021.04.11.21255274.

[41] Chen J, Farah N, Dong RK, Chen RZ, Xu W, Yin A, et al. The Mental Health Under the COVID-19 Crisis in Africa: A Systematic Review and Meta-Analysis. medRxiv. 2021. doi: 10.1101/2021.04.19.21255755.

[42] Salari N, Hosseinian-Far A, Jalali R, Vaisi-Raygani A, Rasoulpoor S, Mohammadi M, et al. Prevalence of stress, anxiety, depression among the general population during the COVID-19 pandemic: a systematic review and meta-analysis. Globalization and Health. 2020;16(1):57. doi: 10.1186/s 12992-020-00589-w.

[43] Batra K, Singh TP, Sharma M, Batra R, Schvaneveldt N. Investigating the Psychological Impact of COVID-19 among Healthcare Workers: A Meta-Analysis. International Journal of Environmental Research and Public Health. 2020;17(23):9096. doi: 10.3390/ijerph17239096. [44] Lin K, Yang BX, Luo D, Liu Q, Ma S, Huang R, et al. The Mental Health Effects of COVID-19 on Health Care Providers in China. The American Journal of Psychiatry. 2020;117(7):635-6. doi: 10.1176/appi.ajp.2020.20040374.

[45] Hale T, Angrist N, Goldszmidt R, Kira B, Petherick A, Phillips T, et al. A global panel database of pandemic policies (Oxford COVID-19 Government Response Tracker). Nature Human Behaviour. 2021;5(4):529-38. doi: 10.1038/s41562-021-01079-8.

[46] Shamseer L, Moher D, Clarke M, Ghersi D, Liberati A, Petticrew M, et al. Preferred reporting items for systematic review and meta-analysis protocols (PRISMA-P) 2015:

elaboration and explanation. BMJ. 2015;349(jan02 1):g7647-g. doi: 10.1136/bmj.g7647. [47] Ransing R, Adiukwu F, Pereira-Sanchez V, Ramalho R, Orsolini L, Teixeira ALS, et al. Mental Health Interventions during the COVID-19 Pandemic: A Conceptual Framework by Early Career Psychiatrists. Asian Journal of Psychiatry. 2020;51:102085. doi:

10.1016/j.ajp.2020.102085.

[48] Debowska A, Horeczy B, Boduszek D, Dolinski D. A repeated cross-sectional survey assessing university students' stress, depression, anxiety, and suicidality in the early stages of the COVID-19 pandemic in Poland. Psychological Medicine. 2020:1-4. doi:

10.1017/S003329172000392X.

[49] Epishin VE, Salikhova AB, Bogacheva NV, Bogdanova MD, Kiseleva MG. Mental Health and the COVID-19 Pandemic: Hardiness and Meaningfulness Reduce Negative Effects on Psychological Well-Being. 2020:14. doi: 10.11621/pir.2020.0405.

[50] Sorokin MY, Kasyanov ED, Rukavishnikov GV, Makarevich OV, Neznanov NG, Lutova NB, et al. Structure of anxiety associated with the COVID-19 pandemic in the Russian-speaking sample: results from on-line survey. preprint. Psychiatry and Clinical Psychology, 2020 2020-0504. Report No.

[51] Maciaszek J, Ciulkowicz M, Misiak B, Szczesniak D, Luc D, Wieczorek T, et al. Mental Health of Medical and Non-Medical Professionals during the Peak of the COVID-19 Pandemic: A Cross-Sectional Nationwide Study. Journal of Clinical Medicine. 2020;9(8):2527. doi: $10.3390 / \mathrm{jcm} 9082527$. 
medRxiv preprint doi: https://doi.org/10.1101/2021.06.21.21259227; this version posted June 25, 2021. The copyright holder for this preprint (which was not certified by peer review) is the author/funder, who has granted medRxiv a license to display the preprint in perpetuity.

It is made available under a CC-BY 4.0 International license .

[52] Assenza G, Lanzone J, Brigo F, Coppola A, Di Gennaro G, Di Lazzaro V, et al. Epilepsy Care in the Time of COVID-19 Pandemic in Italy: Risk Factors for Seizure Worsening. Frontiers in Neurology. 2020;11:737. doi: 10.3389/fneur.2020.00737.

[53] Pylińska-Dąbrowska D, Starzyńska A, Cubała WJ, Ragin K, Alterio D, Jereczek-Fossa BA. Psychological Functioning of Patients Undergoing Oral Surgery Procedures during the Regime Related with SARS-CoV-2 Pandemic. Journal of Clinical Medicine. 2020;9(10):3344. doi: $10.3390 / \mathrm{jcm} 9103344$.

[54] Tysiąc-Miśta M, Dziedzic A. The Attitudes and Professional Approaches of Dental Practitioners during the COVID-19 Outbreak in Poland: A Cross-Sectional Survey. International Journal of Environmental Research and Public Health. 2020;17(13):4703. doi:

10.3390/ijerph17134703.

[55] Izakova L, Breznoscakova D, Jandova K, Valkucakova V, Bezakova G, Suvada J. What mental health experts in Slovakia are learning from COVID-19 pandemic? Indian Journal of Psychiatry. 2020;62(9):459. doi: 10.4103/psychiatry.IndianJPsychiatry_758_20.

[56] Zhang L, Ma M, Li D, Xin Z. The psychological typhoon eye effect during the COVID-19 outbreak in China: the role of coping efficacy and perceived threat. Globalization and Health. 2020;16(1):105. doi: 10.1186/s12992-020-00626-8.

[57] Azoulay E, De Waele J, Ferrer R, Staudinger T, Borkowska M, Povoa P, et al. Symptoms of burnout in intensive care unit specialists facing the COVID-19 outbreak. Annals of Intensive Care. 2020;10(1):110. doi: 10.1186/s13613-020-00722-3.

[58] Dragan M, Grajewski P, Shevlin M. Adjustment disorder, traumatic stress, depression and anxiety in Poland during an early phase of the COVID-19 pandemic. European Journal of Psychotraumatology. 2021;12(1):1860356. doi: 10.1080/20008198.2020.1860356.

[59] Freeman A, Tyrovolas S, Koyanagi A, Chatterji S, Leonardi M, Ayuso-Mateos JL, et al. The role of socio-economic status in depression: results from the COURAGE (aging survey in Europe). BMC Public Health. 2016;16(1):1098. doi: 10.1186/s12889-016-3638-0.

[60] Guasti P. The Impact of the COVID-19 Pandemic in Central and Eastern Europe: The Rise of Autocracy and Democratic Resilience. Democratic Theory. 2020;7(2):47-60. doi:

$10.3167 / \mathrm{dt} .2020 .070207$.

[61] Stroup DF. Meta-analysis of Observational Studies in EpidemiologyA Proposal for Reporting. JAMA. 2000;283(15):2008. doi: 10.1001/jama.283.15.2008.

[62] Chen J, Zhang SX, Wang Y, Jahanshahi AA, Dinanie MM, Madavanif AN, et al. The relationship between age and mental health among adults in Iran during the COVID-19 pandemic. International Journal Of Mental Health and Addiction. in press.

[63] Zhang SX, Chen J, Afshar Jahanshahi A, Alvarez-Risco A, Dai H, Li J, et al. Succumbing to the COVID-19 Pandemic - Healthcare Workers Not Satisfied and Intend to Leave Their Jobs. International Journal of Mental Health and Addiction. 2021. doi: 10.1007/s11469-020-00418-6. [64] Salazar de Pablo G, Vaquerizo-Serrano J, Catalan A, Arango C, Moreno C, Ferre F, et al. Impact of coronavirus syndromes on physical and mental health of health care workers:

Systematic review and meta-analysis. Journal of Affective Disorders. 2020;275:48-57. doi: 10.1016/j.jad.2020.06.022.

[65] Shanafelt T, Ripp J, Trockel M. Understanding and Addressing Sources of Anxiety Among Health Care Professionals During the COVID-19 Pandemic. JAMA. 2020;323(21):2133. doi: 10.1001/jama.2020.5893.

[66] Nochaiwong S, Ruengorn C, Awiphan R, Ruanta Y, Boonchieng W, Nanta S, et al. Mental health circumstances among health care workers and general public under the pandemic situation 
medRxiv preprint doi: https://doi.org/10.1101/2021.06.21.21259227; this version posted June 25, 2021. The copyright holder for this preprint (which was not certified by peer review) is the author/funder, who has granted medRxiv a license to display the preprint in perpetuity.

It is made available under a CC-BY 4.0 International license .

of COVID-19 (HOME-COVID-19). Medicine. 2020;99(26):e20751. doi:

10.1097/MD.0000000000020751.

[67] Horobet A, Simionescu AA, Dumitrescu DG, Belascu L. Europe's War against COVID-19: A Map of Countries' Disease Vulnerability Using Mortality Indicators. International Journal of Environmental Research and Public Health. 2020;17(18). doi: 10.3390/ijerph17186565. [68] Cvetković VM, Nikolić N, Radovanović Nenadić U, Öcal A, K Noji E, Zečević M. Preparedness and Preventive Behaviors for a Pandemic Disaster Caused by COVID-19 in Serbia. International Journal of Environmental Research and Public Health. 2020;17(11). doi: 10.3390/ijerph17114124.

[69] Gater R, Jordanova V, Maric N, Alikaj V, Bajs M, Cavic T, et al. Pathways to psychiatric care in Eastern Europe. The British Journal of Psychiatry: The Journal of Mental Science. 2005;186:529-35. doi: 10.1192/bjp.186.6.529.

[70] Keynejad RC, Bentley A, Bhatia U, Nalwadda O, Mekonnen FD, Ali PA, et al. Research, education and capacity building priorities for violence, abuse and mental health in low- and middle-income countries: an international qualitative survey. Social Psychiatry and Psychiatric Epidemiology. 2021. doi: 10.1007/s00127-021-02061-5.

[71] Hunter JP, Saratzis A, Sutton AJ, Boucher RH, Sayers RD, Bowne MJ. In meta-analyses of proportion studies, funnel plots were found to be an inaccurate method of assessing publication bias. Journal of Clinical Epidemiology. 2014;67(8):897-903. doi: 10.1016/j.jclinepi.2014.03.003. [72] Furuya-Kanamori L, Xu C, Lin L, Doan T, Chud H, Thalib L, et al. P value-driven methods were underpowered to detect publication bias: analysis of Cochrane review meta-analyses. Journal of Clinical Epidemiology. 2020;118:86-92. doi: 10.1016/j.jclinepi.2019.11.011. [73] Kobrinskaya I, Frumkin B. Central-Eastern Europe in Post-COVID-19 International Politics. International Trends / Mezhdunarodnye protsessy. 2020;18(2). doi:

10.17994/IT.2020.18.2.61.1. 
medRxiv preprint doi: https://doi.org/10.1101/2021.06.21.21259227; this version posted June 25, 2021. The copyright holder for this preprint (which was not certified by peer review) is the author/funder, who has granted medRxiv a license to display the preprint in perpetuity.

It is made available under a CC-BY 4.0 International license .

Table 1. Characteristics of the studies on mental health in Eastern Europe during the COVID-19 pandemic

\begin{tabular}{|c|c|c|c|}
\hline Characteristics & $\begin{array}{l}\text { Total number of } \\
\text { studies/samples* }\end{array}$ & Percent & Level of analysis \\
\hline Overall & $21 / 26$ & & \\
\hline Population & & & Study \\
\hline General population & 9 & $42.86 \%$ & \\
\hline General HCWs & 5 & $23.81 \%$ & \\
\hline General students & 4 & $19.05 \%$ & \\
\hline Frontline HCWs & 3 & $14.28 \%$ & \\
\hline Outcome\# & & & Prevalence \\
\hline Anxiety & 44 & $50.57 \%$ & \\
\hline Depression & 43 & $49.43 \%$ & \\
\hline Severity\# & & & Prevalence \\
\hline Above mild & 30 & $34.48 \%$ & \\
\hline Above moderate & 33 & $37.93 \%$ & \\
\hline Above severe & 17 & $19.54 \%$ & \\
\hline Overall & 7 & $8.05 \%$ & \\
\hline Sampling country & & & Study \\
\hline Albania & 2 & $9.52 \%$ & \\
\hline Bosnia and Herzegovina & 1 & $4.76 \%$ & \\
\hline Bulgaria & 1 & $4.76 \%$ & \\
\hline Croatia & 3 & $14.29 \%$ & \\
\hline Czech & 1 & $4.76 \%$ & \\
\hline Kosovo & 1 & $4.76 \%$ & \\
\hline Poland & 4 & $19.05 \%$ & \\
\hline Russia & 3 & $14.29 \%$ & \\
\hline Serbia & 4 & $19.05 \%$ & \\
\hline Ukraine & 1 & $4.76 \%$ & \\
\hline Quality & & & Study \\
\hline High & 3 & $14.29 \%$ & \\
\hline Medium & 18 & $85.71 \%$ & \\
\hline Study design & & & Study \\
\hline Cohort & 1 & $4.76 \%$ & \\
\hline Cross-sectional & 20 & $95.24 \%$ & \\
\hline Publication & & & Study \\
\hline Preprint & 2 & $9.52 \%$ & \\
\hline Published & 29 & $90.48 \%$ & \\
\hline & Mean (Median) & Range & \\
\hline Number of participants & $971(843)$ & $83-3306$ & Sample \\
\hline Female proportion & $69.2 \%(68.8 \%)$ & $43.1 \%-88.6 \%$ & Sample \\
\hline Response rate & $54.2 \%(56.7 \%)$ & $0.7 \%-98.5 \%$ & Sample \\
\hline
\end{tabular}

* A study may include multiple independent samples.

\# An independent sample in a study may report anxiety, depression, and insomnia at the levels of mild above, moderate above, and severe. Hence, the total number of prevalence rates is larger than the total number of independent samples. 
Table 2. The pooled prevalence rates of mental health symptoms by subgroups of population, outcome, severity, region, and quality

\begin{tabular}{lrrrrr}
\hline $\begin{array}{l}\text { First-level } \\
\text { subgroup }\end{array}$ & $\begin{array}{r}\text { Second-level } \\
\text { subgroup }\end{array}$ & $\begin{array}{r}\text { Prevalence } \\
(\%)\end{array}$ & $\begin{array}{r}95 \% \text { CI } \\
(\%)\end{array}$ & $I^{2}(\%)$ & P value \\
\hline \multirow{4}{*}{ Outcome } & Aggregated & $28 \%$ & $24-33$ & 99.6 & 0.00 \\
& Anxiety & $30 \%$ & $24-37$ & 99.6 & 0.00 \\
& Depression & $27 \%$ & $21-34$ & 99.6 & 0.00 \\
\hline \multirow{4}{*}{ Population } & Frontline HCWs & $41 \%$ & $23-60$ & 99.4 & 0.00 \\
& General HCWs & $33 \%$ & $22-45$ & 99.5 & 0.00 \\
& General population & $21 \%$ & $16-26$ & 99.7 & 0.00 \\
& General students & $31 \%$ & $20-44$ & 99.6 & 0.00 \\
\hline \multirow{4}{*}{ Severity } & Above mild & $52 \%$ & $43-60$ & 98.5 & 0.00 \\
& Above moderate & $24 \%$ & $20-28$ & 98.1 & 0.00 \\
& Above severe & $11 \%$ & $9-13$ & 95.2 & 0.00 \\
EU & Overall & $12 \%$ & $8-18$ & 99.1 & 0.00 \\
\hline membership & EU countries & $34 \%$ & $27-42$ & 99.7 & 0.00 \\
\multirow{2}{*}{ Region } & Non-EU countries & $28 \%$ & $22-35$ & 99.8 & 0.00 \\
\hline \multirow{2}{*}{ Quality } & Southeastern & $27 \%$ & $22-32$ & 99.4 & 0.00 \\
& Europe & & & & \\
& Non-Southeastern & $32 \%$ & $24-40$ & 99.7 & 0.00 \\
\hline
\end{tabular}

Note: $\mathrm{CI}=$ Confidence Interval. $\mathrm{I}^{2}$ statistic indicates the heterogeneity across the studies. 
medRxiv preprint doi: https://doi.org/10.1101/2021.06.21.21259227; this version posted June 25, 2021. The copyright holder for this preprint (which was not certified by peer review) is the author/funder, who has granted medRxiv a license to display the preprint in perpetuity.

It is made available under a CC-BY 4.0 International license .

Table 3. Subgroup analyses of anxiety and depression prevalence

\begin{tabular}{|c|c|c|c|}
\hline Groups & Subgroups & Anxiety & Depression \\
\hline \multicolumn{2}{|c|}{ Number of studies } & 18 & 18 \\
\hline \multicolumn{2}{|c|}{ Number of samples } & 22 & 23 \\
\hline \multicolumn{2}{|c|}{ Number of prevalence rates } & 44 & 43 \\
\hline \multicolumn{2}{|c|}{ Number of participants } & 21,120 & 22,195 \\
\hline \multicolumn{2}{|l|}{ Aggregated } & $\begin{array}{l}\text { 30\%, 95\% CI: } 24 \%-37 \% \text {, } \\
\mathrm{I}^{2}: 99.6 \%\end{array}$ & $\begin{array}{l}\mathbf{2 7 \%} \%, 95 \% \text { CI: } 21 \%-34 \% \text {, } \\
\text { I }^{2}: 99.6 \%\end{array}$ \\
\hline \multirow[t]{4}{*}{ Population } & $\begin{array}{r}\text { Frontline } \\
\text { HCWs }\end{array}$ & $\begin{array}{l}46 \%, 95 \% \text { CI: } 25 \%-67 \%, \\
I^{2}: 99.4 \%\end{array}$ & $\begin{array}{l}\text { 34\%, 95\% CI: } 2 \%-79 \% \\
\mathrm{I}^{2}: 99.5 \%\end{array}$ \\
\hline & General HCWs & $\begin{array}{l}\text { 33\%, 95\% CI: } 16 \%-51 \% \text {, } \\
\mathrm{I}^{2}: 99.5 \%\end{array}$ & $\begin{array}{l}\text { 34\%, 95\% CI: } 18 \%-51 \% \text {, } \\
\mathrm{I}^{2}: 99.5 \%\end{array}$ \\
\hline & $\begin{array}{r}\text { General } \\
\text { population }\end{array}$ & $\begin{array}{l}\mathbf{2 2} \%, 95 \% \text { CI: } 15 \%-31 \% \text {, } \\
\text { I }^{2}: 99.6 \%\end{array}$ & $\begin{array}{l}\mathbf{2 0} \%, 95 \% \text { CI: } 13 \%-27 \% \text {, } \\
\text { I }^{2}: 99.5 \%\end{array}$ \\
\hline & General student & $\begin{array}{l}\text { 31\%, 95\% CI: } 15 \%-50 \% \text {, } \\
\mathrm{I}^{2}: 99.7 \%\end{array}$ & $\begin{array}{l}\text { 32\%, } 95 \% \text { CI: } 16 \%-50 \% \text {, } \\
\mathrm{I}^{2}: 99.6 \%\end{array}$ \\
\hline \multirow[t]{4}{*}{ Severity } & Above mild & $\begin{array}{l}\mathbf{5 6 \%}, 95 \% \text { CI: } 44 \%-67 \% \text {, } \\
I^{2}: 99.4 \%\end{array}$ & $\begin{array}{l}\mathbf{4 8 \%} \%, 95 \% \text { CI: } 36 \%-60 \% \text {, } \\
\mathrm{I}^{2}: 99.6 \%\end{array}$ \\
\hline & $\begin{array}{l}\text { Above } \\
\text { moderate }\end{array}$ & $\begin{array}{l}\mathbf{2 6 \%}, 95 \% \text { CI: } 20 \%-32 \% \text {, } \\
I^{2}: 98.6 \%\end{array}$ & $\begin{array}{l}\mathbf{2 2} \%, 95 \% \text { CI: } 17 \%-26 \% \text {, } \\
\mathrm{I}^{2}: 96.8 \%\end{array}$ \\
\hline & Severe & $\begin{array}{l}\text { 12\%, } 95 \% \text { CI: } 9 \%-15 \% \\
\mathrm{I}^{2}: 95.6 \%\end{array}$ & $\begin{array}{l}\mathbf{1 0} \%, 95 \% \text { CI: } 7 \%-13 \% \\
\mathrm{I}^{2}: 94.8 \%\end{array}$ \\
\hline & Overall & $\begin{array}{l}\text { 15\%, } 95 \% \text { CI: } 8 \%-24 \% \text {, } \\
\mathrm{I}^{2}: 99.2 \%\end{array}$ & 9\%, 95\% CI: 4\%-17\% \\
\hline \multirow[t]{2}{*}{$\begin{array}{l}\text { EU } \\
\text { membership }\end{array}$} & EU countries & $\begin{array}{l}\mathbf{2 8 \%}, 95 \% \text { CI: } 20 \%-38 \% \text {, } \\
\mathrm{I}^{2}: 99.5 \%\end{array}$ & $\begin{array}{l}\mathbf{3 6 \%} \% \text { 95\% CI: } 24 \%-48 \% \text {, } \\
\mathrm{I}^{2}: 99.7 \%\end{array}$ \\
\hline & $\begin{array}{l}\text { Non-EU } \\
\text { countries }\end{array}$ & $\begin{array}{l}\mathbf{2 9} \%, 95 \% \text { CI: } 20 \% 40 \% \text {, } \\
\mathrm{I}^{2}: 99.8 \%\end{array}$ & $\begin{array}{l}\mathbf{2 7 \%}, 95 \% \text { CI: } 18 \%-37 \% \text {, } \\
\mathrm{I}^{2}: 99.6 \%\end{array}$ \\
\hline \multirow[t]{2}{*}{ Region } & $\begin{array}{r}\text { Southeastern } \\
\text { Europe (Greater } \\
\text { Balkan region) }\end{array}$ & $\begin{array}{l}\mathbf{3 1} \%, 95 \% \text { CI: } 27 \%-40 \% \text {, } \\
\mathrm{I}^{2}: 99.5 \%\end{array}$ & $\begin{array}{l}\mathbf{3 5 \%} \% \text { 95\% CI: } 21 \%-51 \% \text {, } \\
\mathrm{I}^{2}: 99.4 \%\end{array}$ \\
\hline & $\begin{array}{r}\text { Non- } \\
\text { Southeastern } \\
\text { Europe } \\
\end{array}$ & $\begin{array}{l}\mathbf{2 9 \%}, 95 \% \text { CI: } 20 \%-40 \% \text {, } \\
\mathrm{I}^{2}: 99.6 \%\end{array}$ & $\begin{array}{l}\mathbf{5 5 \%}, 95 \% \text { CI: } 46 \%-65 \% \text {, } \\
\mathrm{I}^{2}: 99.8 \%\end{array}$ \\
\hline \multirow[t]{5}{*}{ Instruments } & GAD-7/PHQ-9 & $\begin{array}{l}\text { 34\%, 95\% CI: } 25 \%-44 \% \text {, } \\
\mathrm{I}^{2}: 99.6 \%\end{array}$ & $\begin{array}{l}\text { 35\%, 95\% CI: } 35 \%-57 \% \text {, } \\
I^{2}: 99.6 \%\end{array}$ \\
\hline & DASS-21 & $\begin{array}{l}\mathbf{2 5 \%}, 95 \% \text { CI: } 16 \%-34 \% \text {, } \\
\text { I }^{2}: 99.1 \%\end{array}$ & $\begin{array}{l}\mathbf{2 8 \%}, 95 \% \text { CI: } 20 \%-36 \% \text {, } \\
\text { I }^{2}: 98.8 \%\end{array}$ \\
\hline & HADS & $\begin{array}{l}\mathbf{4 3} \%, 95 \% \text { CI: } 17 \%-71 \% \text {, } \\
\mathrm{I}^{2}: 99.1 \%\end{array}$ & $\begin{array}{l}\text { 33\%, 95\% CI: 7\% - 67\%, } \\
\mathrm{I}^{2}: 99.7 \%\end{array}$ \\
\hline & BDI & $\begin{array}{l}\mathbf{5 \%}, 95 \% \text { CI: } 3 \%-9 \%, I^{2}: \\
98.8 \%\end{array}$ & $\begin{array}{l}12 \%, 95 \% \text { CI: } 4 \%-24 \% \text {, } \\
\mathrm{I}^{2}: 97.5 \%\end{array}$ \\
\hline & SDS & NA & $\begin{array}{l}\mathbf{1 0} \%, 95 \% \text { CI: } 3 \%-20 \% \\
\mathrm{I}^{2}: 88.8 \%\end{array}$ \\
\hline
\end{tabular}

Note: $\mathrm{CI}=$ Confidence Interval; $\mathrm{I}^{2}$ statistic indicates heterogeneity. 
medRxiv preprint doi: https://doi.org/10.1101/2021.06.21.21259227; this version posted June 25, 2021. The copyright holder for this preprint (which was not certified by peer review) is the author/funder, who has granted medRxiv a license to display the preprint in perpetuity.

It is made available under a CC-BY 4.0 International license.
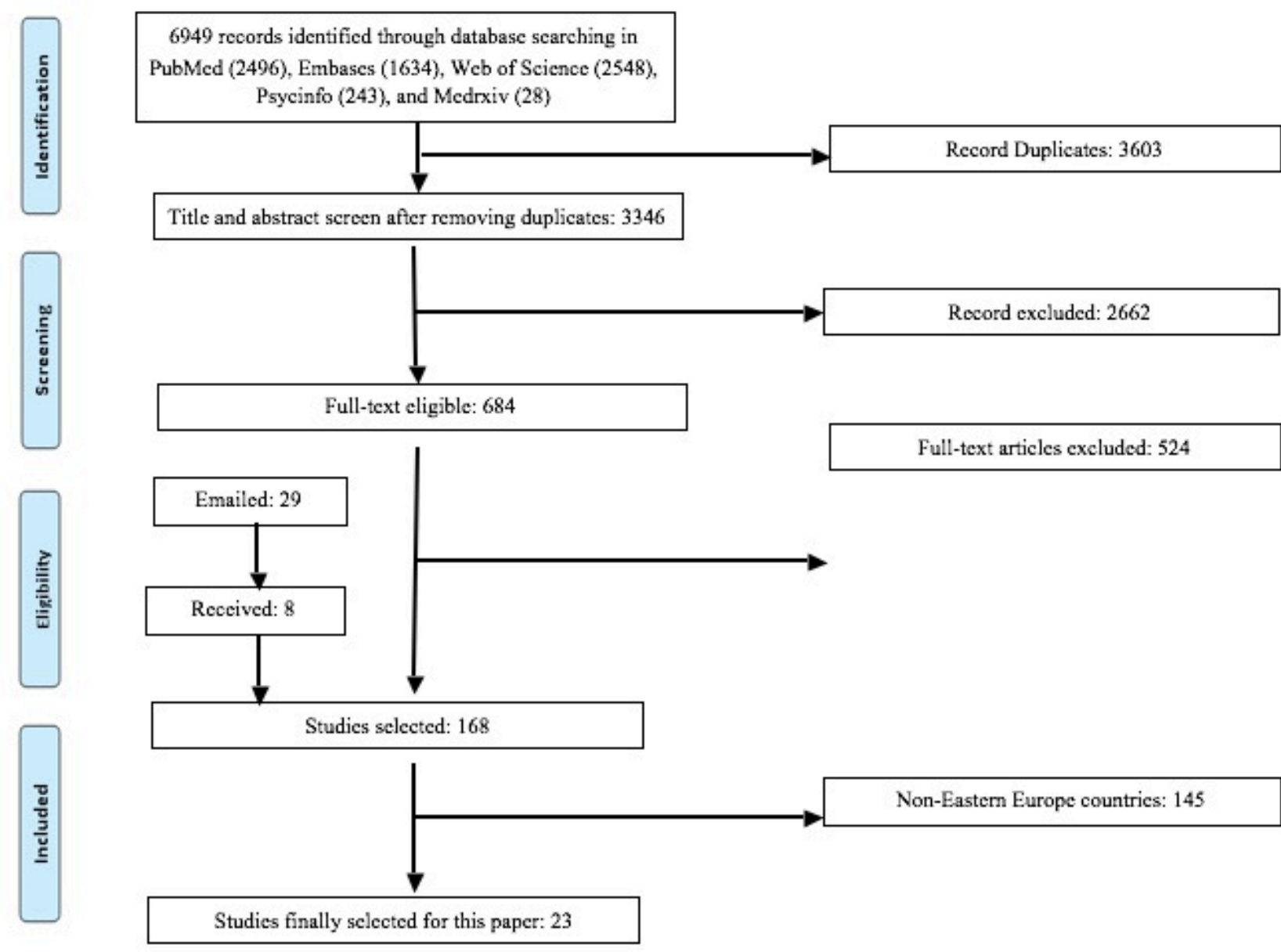

Figure 1. A PRISMA flow diagram.

As there were only two studies on insomnia, they were excluded. The final number of studies included in the meta-analysis is 21 . 
medRxiv preprint doi: https://doi.org/10.1101/2021.06.21.21259227; this version posted June 25, 2021. The copyright holder for this preprint (which was not certified by peer review) is the author/funder, who has granted medRxiv a license to display the preprint in perpetuity.

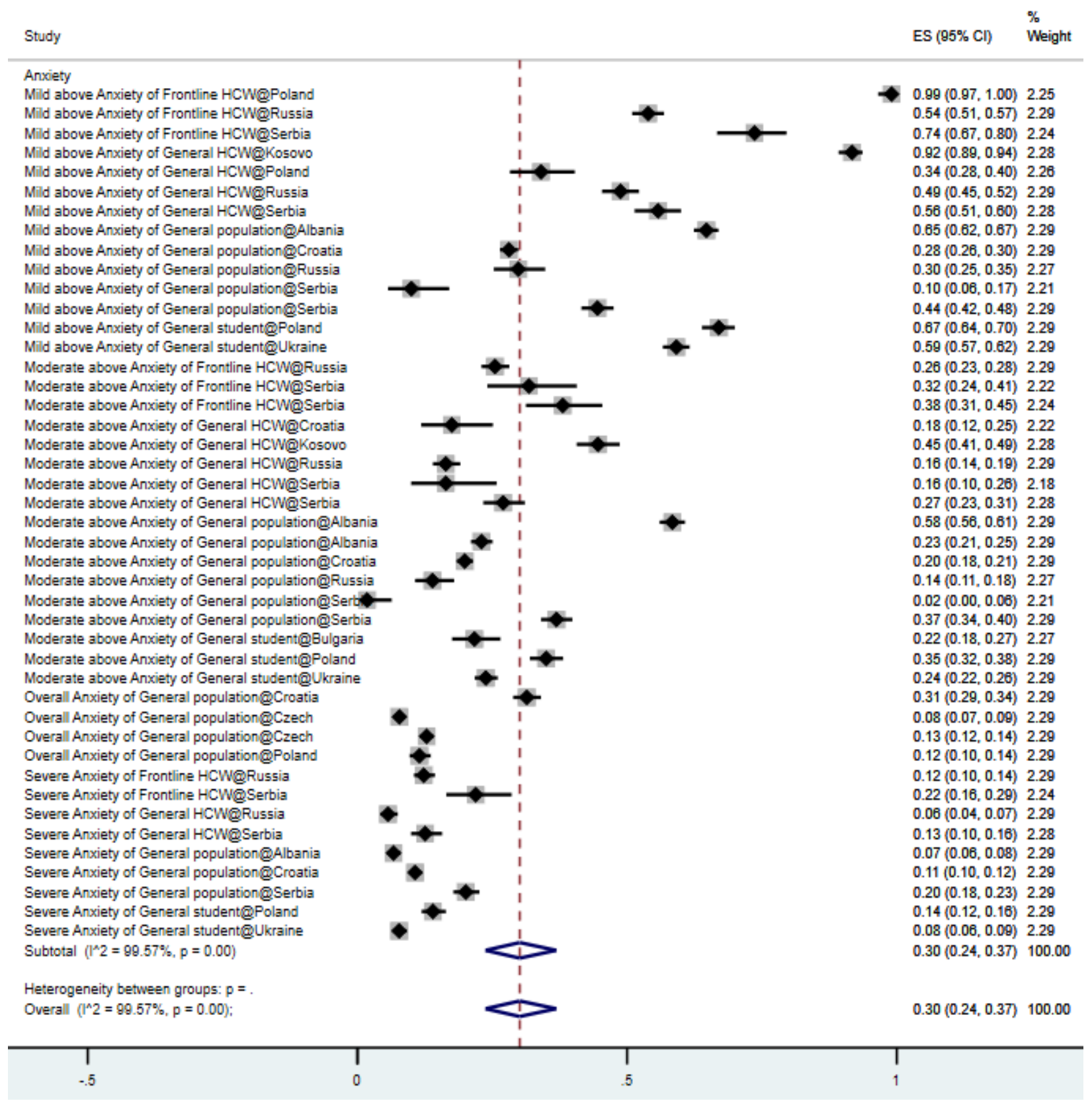

Figure 2A. Forest plot of anxiety prevalence

Figure legend: The square markers indicate the prevalence of anxiety at the different levels for different populations. The size of the marker correlates to the inverse variance of the effect estimate and indicates the weight of the study. The diamond data marker indicates the pooled prevalence. The vertical dashed line represents the line of null effect. 
medRxiv preprint doi: https://doi.org/10.1101/2021.06.21.21259227; this version posted June 25, 2021. The copyright holder for this preprint (which was not certified by peer review) is the author/funder, who has granted medRxiv a license to display the preprint in perpetuity.

It is made available under a CC-BY 4.0 International license .

\section{Depression}

Mild above Depression of Frontline HCW gPoland Mild above Depression of General HCW@Kascvo Mild above Depression of General HCW@Paland Mild above Depression of General HCW@Paland Mild above Depression of General HCW@Russia Mild above Depression of General HCW@Serbia Mild above Depression of General population@N/bania Mild above Depression of General population@Abania Mild above Depression of General population@Croatia Mild above Depression of General population@Russia Mild above Depression of General population@Sertia Mild above Depression of General population@Serbia Mild above Depression of General student@Albania Moderate above Depression of Frontline HCWQSerbia Moderate abave Depression of Frontline HCW@Serbia Moderate abave Depression of General HCW@Craatia Moderate abave Depression of General HCW@Kasowa Moderate abave Depression of General HCW@Russia Moderate abave Depression of General HCW@Sertia Moderate above Depression of General HCW@Sertia Moderate above Depression of General population@Abaria Moderate abave Depression of General populaticn@Croatia Moderate above Depression of General population@Russia Moderate abave Depression of General population@Serbia Moderate abave Depression of General papulation@Serbia Moderate abave Depression of General student BA Abaris Moderate abave Depression of General studentigBulgaria Moderate abave Depression of General studentQUUkraine Overall Depressian of General population@Croatia Overall Depression of General population @Czech Severe Depression of Frontline HCW@Serbia Severe Depression of General HCW Russia Severe Depression of General HCW Severe Depression of General population BBosnia and Herzegovina Severe Depression of General population BCroatia Severe Depression of General populationgSerbia Severe Depression of General studentgAlbania Severe Depression of General studentQUkraine Subtotal $\left(I^{\wedge} 2=99.57 \%, p=0.00\right)$

Heterogeneity between groups: $p=$ Overall $\left(I^{\wedge} 2=99.57 \%, p=0.00\right)$; Mild above Depression of Frontine HCW gSerbia Mild above Depression of General population@Poland Mild above Depression of General student@Ukraine Moderate above Depression of General population@Bosnia and Herzegowina Overall Depression of General populatianigCzech

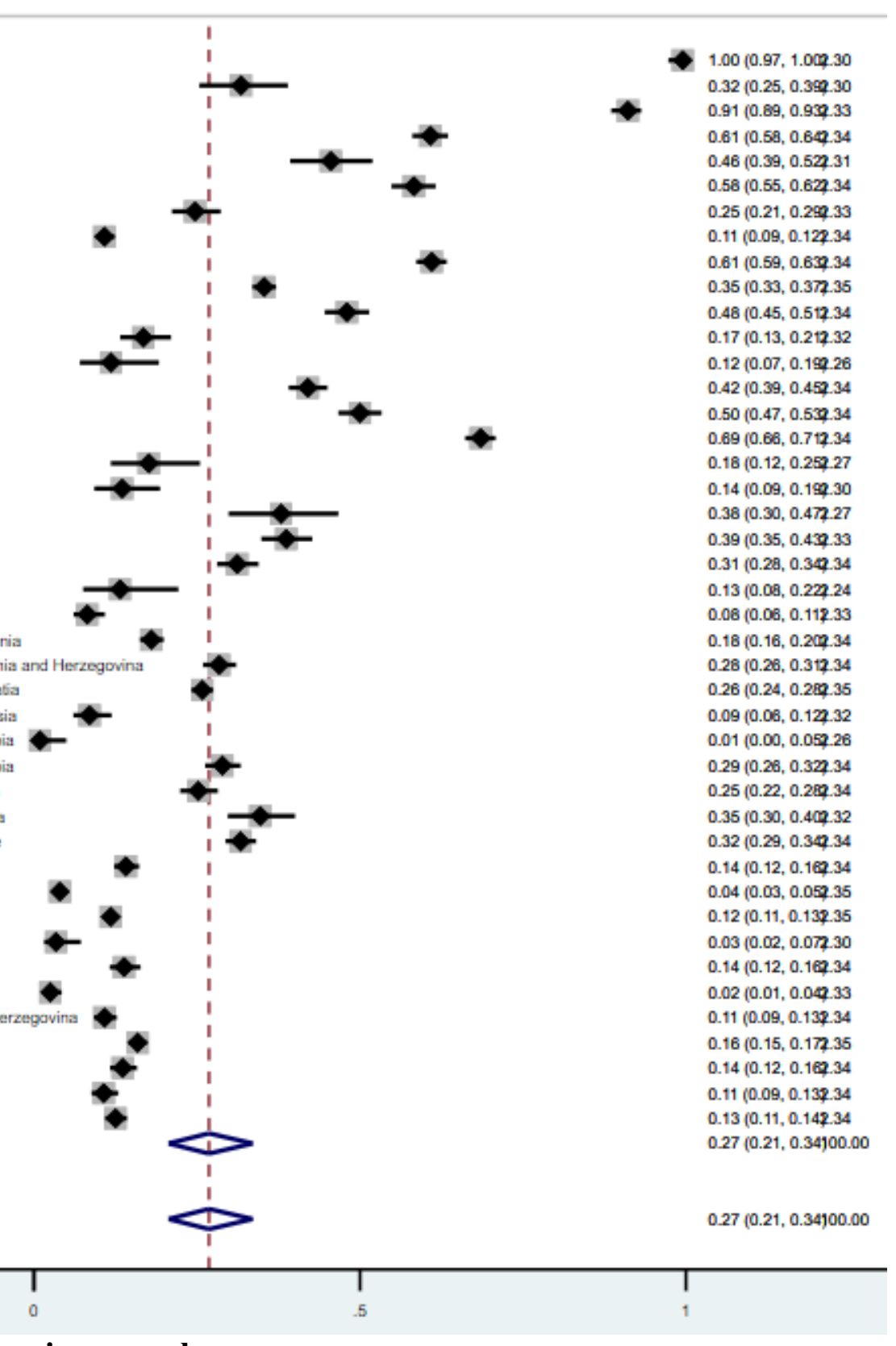

Figure 2B. Forest plot of depression prevalence

Figure legend: The square markers indicate the prevalence of depression at the different levels for different populations. The size of the marker correlates to the inverse variance of the effect estimate and indicates the weight of the study. The diamond data marker indicates the pooled prevalence. The vertical dashed line represents the line of null effect. 
LFK index $=1.50$ (minor asymmetry)

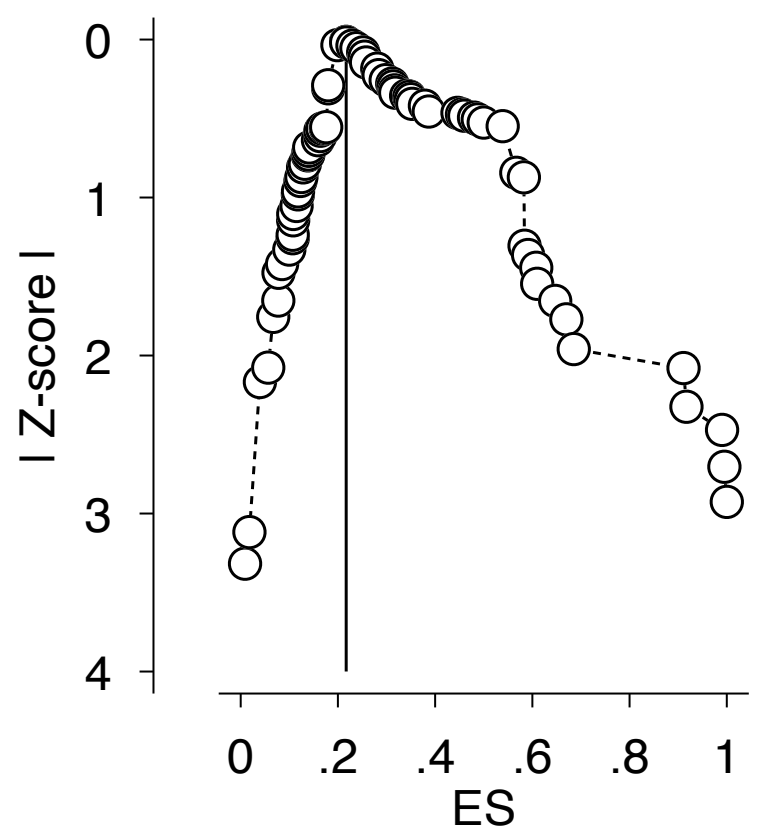

Figure 3. Luis Furuya-Kanamori Index indication of publication bias.

Publication bias in the baseline meta-analysis is graphically represented using a DOI plot along with a Luis Furuya-Kanamori (LFK) index score. A score of 1.50 indicates 'minor asymmetry' and therefore minor publication bias. 
medRxiv preprint doi: https://doi.org/10.1101/2021.06.21.21259227; this version posted June 25, 2021. The copyright holder for this preprint (which was not certified by peer review) is the author/funder, who has granted medRxiv a license to display the preprint in perpetuity.

It is made available under a CC-BY 4.0 International license .

\section{Appendix 1: The search strategy of this systematic review and meta-analysis}

\begin{tabular}{|l|l|l|}
\hline Search query & Search topic & $\begin{array}{l}\text { Search keywords (titles, abstracts, and subject } \\
\text { headings) with Boolean operators }\end{array}$ \\
\hline $\mathbf{1}$ & $\begin{array}{l}\text { Exposure/ } \\
\text { Context }\end{array}$ & $\begin{array}{l}\text { "Coronavirus" OR "COVID-19" OR "SARS-CoV-2" } \\
\text { OR "2019-nCoV" }\end{array}$ \\
\hline $\mathbf{2}$ & $\begin{array}{l}\text { Outcome of } \\
\text { interest } \\
\text { "Depression" OR "Depressive symptoms" OR } \\
\text { anxiety" or "Social phobia" OR "Anxiety disorder" OR } \\
\text { "Insomnia" OR "Sleep disorder" OR "Depressive } \\
\text { disorder*" }\end{array}$ \\
\hline $\mathbf{3}$ & $\begin{array}{l}\text { Epidemiological } \\
\text { phenomenon }\end{array}$ & $\begin{array}{l}\text { "Prevalence" OR "Incidence" OR "rate*" OR "ratio*” } \\
\text { OR "Epidemiolog" OR "risk factor" OR "relative risk" } \\
\text { OR "odds ratio" OR "risk ratio" OR "disease burden" }\end{array}$ \\
\hline $\mathbf{4}$ & Language & English \\
\hline $\begin{array}{l}\text { Final search } \\
\text { query }\end{array}$ & $\begin{array}{l}\text { Intersection of } \\
\text { four topics }\end{array}$ & 1 AND 2 AND 3 AND 4 \\
\hline
\end{tabular}


medRxiv preprint doi: https://doi.org/10.1101/2021.06.21.21259227; this version posted June 25, 2021. The copyright holder for this preprint (which was not certified by peer review) is the author/funder, who has granted medRxiv a license to display the preprint in perpetuity.

It is made available under a CC-BY 4.0 International license.

\section{Author contributions}

All authors declare they meet ICMJE conditions for authorship. SZ, RKD and JC designed the coding guide and method and performed the initial literature search. SZ, SM, and JC performed statistical analysis and led the drafting and editing of the article. RSM edited the article. SM, WX, AY, BZC, AD, RKD, RZC and XW collected the data. All authors approved the final version of the article.

\section{A conflict-of-interest statement}

There are no conflicts of interest.

\section{Transparency declaration}

The corresponding author affirms this manuscript is an honest, accurate, and transparent account of the study being reported. No important aspects of the study have been omitted and any discrepancies from the study as planned (and, if relevant, registered) have been explained.

\section{Ethical approval}

Not applicable.

\section{Funding}

Jiyao Chen has received $\$ 5000$ research support from College of Business Oregon State University.

\section{Patient and public involvement}

No patient or public was involved in this systematic review and meta-analysis.

\section{Availability of data}

The data that support the findings of this study are available from the corresponding author,

J.C., upon reasonable request.

\section{Disclosure}


medRxiv preprint doi: https://doi.org/10.1101/2021.06.21.21259227; this version posted June 25, 2021. The copyright holder for this preprint (which was not certified by peer review) is the author/funder, who has granted medRxiv a license to display the preprint in perpetuity.

It is made available under a CC-BY 4.0 International license.

Dr. Roger McIntyre has received research grant support from CIHR/GACD/Chinese National

Natural Research Foundation; speaker/consultation fees from Lundbeck, Janssen, Purdue,

Pfizer, Otsuka, Takeda, Neurocrine, Sunovion, Bausch Health, Novo Nordisk, Kris, Sanofi, Eisai

,Intra-Cellular, NewBridge Pharmaceuticals, Abbvie. Dr. Roger McIntyre is a CEO of Braxia

Scientific Corp. 